\title{
頝動脈プラークイメージングの現状と展望
}

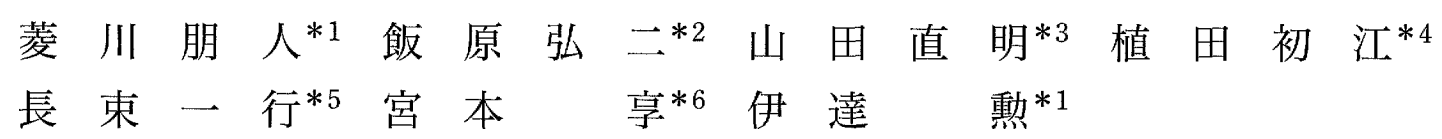

\section{Carotid Artery Plaque Imaging : Present Status and New Perspectives}

by

Tomohito Hishikawa, M.D. ${ }^{* 1}$, Koji Iihara, M.D. ${ }^{* 2}$, Naoaki Yamada, M.D. ${ }^{* 3}$, Hatsue Ueda, M.D. ${ }^{* 4}$, Kazuyuki Nagatsuka, M.D. ${ }^{* 5}$, Susumu Miyamoto, M.D. ${ }^{* 6}$, and Isao Date, M.D. ${ }^{* 1}$

from

${ }^{* 1}$ Department of Neurological Surgery, Okayama University Graduate School of Medicine

Department of ${ }^{* 2}$ Cerebrovascular Surgery, ${ }^{* 3}$ Radiology, ${ }^{* 4}$ Pathology, and ${ }^{* 5}$ Cerebrovascular Division, National Cerebral and Cardiovascular Center Hospital

${ }^{* 6}$ Department of Neurosurgery, Kyoto University Graduate School of Medicine

At present, the management of carotid artery (CA) stenosis depends largely on the degree of stenosis. CA plaque imaging is a modality, which assesses the nature of CA plaques objectively and less invasively, that has developed remarkably in recent years. The use of CA plaque imaging in the management of CA stenosis not only reveals the degree of stenosis but it can make the selection of treatment more appropriate by taking the plaque character into consideration. In this manuscript, we introduce ultrasound, intravascular ultrasound, angiography, magnetic resonance imaging (MRI), positron emission tomography (PET) and computed tomography (CT) and describe the present situation and new perspectives of CA plaque imaging.

(Received May 28, 2010; accepted July 5, 2010)

Key words : carotid artery plaque, imaging, vulnerability

Jpn J Neurosurg (Tokyo) $19: 836-843,2010$

\section{はじめに}

頝動脈狭窄症に対する内膜血栓剝離術（carotid endarterectomy：CEA）の有效性は，いくつかの無作為比較試 験で証明された ${ }^{9) 1013) 29)}$ 。これらの科学的根拠に基づく 現存の手術適応は, 狭窄率, 症状の有無, 周術期合併症 率によってのみ規定されている。一方で冠動脈病変にお いては, 急性心筋梗塞の $68 \%$ $50 \%$ 以下の狭窄である との報告11)から，狭窄率だけでなくプラーク性状，言い
換えれば vulnerable plaque の評価が重要視されている. 同様に頝動脈病変においても, 虚血隹げントが高度狭窄 のみに限定されないことから ${ }^{3) 12235)}$ ，近年種々の modality を駆使した額動脈プラーク性状評価（頝動脈プラーク イメージング）が施行されている。このプラーク性状評 価と相まって「不安定プラーク」という表現が頻用され ている.この「不安定プラーク」は包括的な terminology であり, 病理学的な vulnerability を基盤とし, 症候化に 至りやすいプラークや外科手技中に塞栓性合併症をきた

\footnotetext{
*1岡山大学大学院医歯薬学総合研究科脑神経外科 $/$ T 700-8558 岡山市北区鹿田町 2-5-1〔連絡先: 菱川朋人〕

Address reprint requests to: Tomohito Hishikawa, M.D., Department of Neurological Surgery, Okayama University Graduate School of Medicine, 2-5-1 Shikata-cho, Kita-ku, Okayama-shi, Okayama 700-8558, Japan

国立循環器病研究センター*2脳神経外科, *3放射線診療部, *4病理部, *5脳血管内科

*6京都大学大学院医学系研究科脳神経外科
} 
しやすいプラークなどの要素を包含している，頝動脈プ ラークイメージングは，こ机らのプラークの不安定性を 構成する要素を客観的にかつ非侵襲的に評価する役割を 担っている.

本論文では，最初に病理学的な vulnerable plaque につ いて概説し，超音波検査（頝動脈エコー），血管内超音波 (intravascular ultrasound: IVUS), 脳血管造影, magnetic resonance imaging (MRI), positron emission tomography (PET), computed tomography（CT）における頝動脈プ ラークイメージングの現状と展望について述べる。

\section{病理学的な vulnerable plaque}

病理学的な vulnerable plaque とは,「血栓を形成しや すく，急速に進行する可能性の高いプラーク」と定義さ れる ${ }^{25)}$. Naghavi ら ${ }^{25)}$ は, 冠動脈病変において autopsy study を基に vulnerable plaque の基準を提唱している. 大項目として, (1)active inflammation（活動性の高い炎 症)，(2)thin cap with a large lipid core（大きな脂質コアを 有する薄い被膜), (3)endothelial denudation with superficial platelet aggregation（血管内皮の脱落と表面への血小 板凝集)，(4)fissured/injured plaque（プラークの損傷）, (5)severe stenosis (高度狭窄), 小項目として(1)superficial calcified nodule (表面の石灰化と結節), (2)yellow color on angioscopy（血管内視鏡で黄色調を呈するプラーク), (3) intraplaque hemorrhage (プラーク内出血), (4)endothelial dysfunction (血管内皮機能不全), (5)expansive remodeling (広範なりモデリング)を提唱した. Redgrave ら ${ }^{32}$ )が検討 した大規模な The Oxford Plaque Study では, 症候性頚動 脈病変と炎症（マクロファージの浸潤）の有意な相関が 報告されている. Kolodgie ら ${ }^{20)}$ は, 赤血球膜蛋白に含ま れる大量の free cholesterol が necrotic core の増大の源 泉であり，また出血によりマクロファージが誘導され fibrous cap の菲薄化をもたらすなどプラーク内出血が vulnerability を高める主な要因としている。これら種々 の報告から, vulnerable plaque の病理所見の特徵は, (1) large necrotic core with intraplaque hemorrhage (プラーク 内出血を有する大きな壞死性コア), (2)inflammation (macrophage infiltration) (炎症〔マクロファージの浸 潤了), (3)thin fibrous cap (薄い線維性被膜)に集約される。

\section{各 modality におけるプラークイメージング}

\section{1 超音波検査 (頚動脈エコー)}

超音波検査はその非侵襲性ならびに簡便性の点で, 最
も頻繁に臨床で使用されているプラークイメージング の1つである.プラーク性状を評価する主なパラメー ターはエコー輝度 (echogenicity) と均一性 (heterogeneity)であり,これら 2 つを組み合わせて判断する。エコー 輝度は低輝度 (hypoechoic, echolucent), 等輝度 (isoechoic, echogenic), 高輝度 (hyperechoic, calcified) に分類され, 均一性は均一 (homogeneous), 不均一 (heterogeneous）に分類される. Polak $5^{311}$ は，65歳以上の 低煇度プラークは脳卒中発生の独立した危険因子である

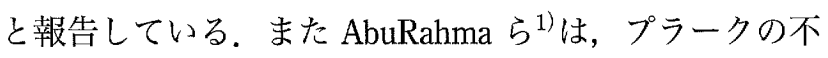
均一性は狭窄率よりも虚血イベントにより相関している と論じている. エコー輝度と均一性以外に, 超音波検查 の利点はリアルタイムに可動性が把握できる点にあ る ${ }^{24)}$. 可動性は不安定プラークの重要な要因である.

超音波検査は外来で繰り返し施行可能で, 狭窄率の測 定やプラークの形態変化の把握や薬物の效果判定には有 用であるが，欠点はその主観性にある。通常の超音波検 査は gray scale で描出され，その読影は検者の主観に委 小られる。近年, 客観性を高めるため信号強度を定量化 し積分する integrated backscatter という手法も報告され ている ${ }^{24)}$.

\section{2 血管內超音波（IVUS）}

頝動脈病変における IVUS の有用性は，特にステント 留置術 (carotid artery stenting: CAS) において論じられ

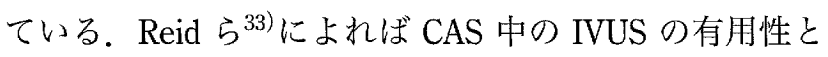
して, (1)正確な血管径の把握, (2)完全なステント留置の 把握，(3)遠位塞栓の予知を挙げている。手技中にこれら の情報が得られることは, 安全にCAS を施行するうえで 重要であるが，経皮的な䅡動脈エコーと同様に，その主 観性に問題があり，必ずしも実際の病理組織を反映して いないといつた課題も提起されている ${ }^{28)}$.この主観性を 克服すべく開発されたのが, Virtual-histology (VH)IVUS である ${ }^{26)}$ V VH アルゴリズムでは, エコー強度に周 波数を加味し,プラークの構成成分を fibrous tissue(緑), fibro-fatty (黄緑), necrotic core (赤), dense calcium （白）の 4 種類に自動的に分類・表示する. 各成分にお いてVH 画像は高い精度で病理組織と合致することが 報告されている ${ }^{26)}$. 元来, 冠動脈用に開発され, 冠動脈 領域では確立された modality として臨床使用されてお り，その有用性を論じた報告も多数存在する ${ }^{18) 19) 27)}$. $\mathrm{VH}-$ IVUS の頚動脈病変への応用も報告されているが722), わ れわれ ${ }^{15)}$ は CEA 摘出標本を用いて ex vivo で $\mathrm{VH}$ 画像と 病理組織の比較検討を行つた。結果, VH では病理組織 に比較して necrotic core は有意に過小評価されていた 
Table 1 Medians (interquartile range) of the necrotic core area for IPH scores 1,2 , and 3 in histological sections

\begin{tabular}{|c|c|c|}
\hline & Necrotic core area (\%) & $\mathrm{p}$ value \\
\hline IPH score 1 & $32.7(\mathrm{IQR}, 24.9-46.4)$ & \\
\hline IPH score 2 & 46.9 (IQR, 41.4-53.5) & $<0.0001$ \\
\hline IPH score 3 & $53.1(\mathrm{IQR}, 47.8-65.4)$ & \\
\hline
\end{tabular}
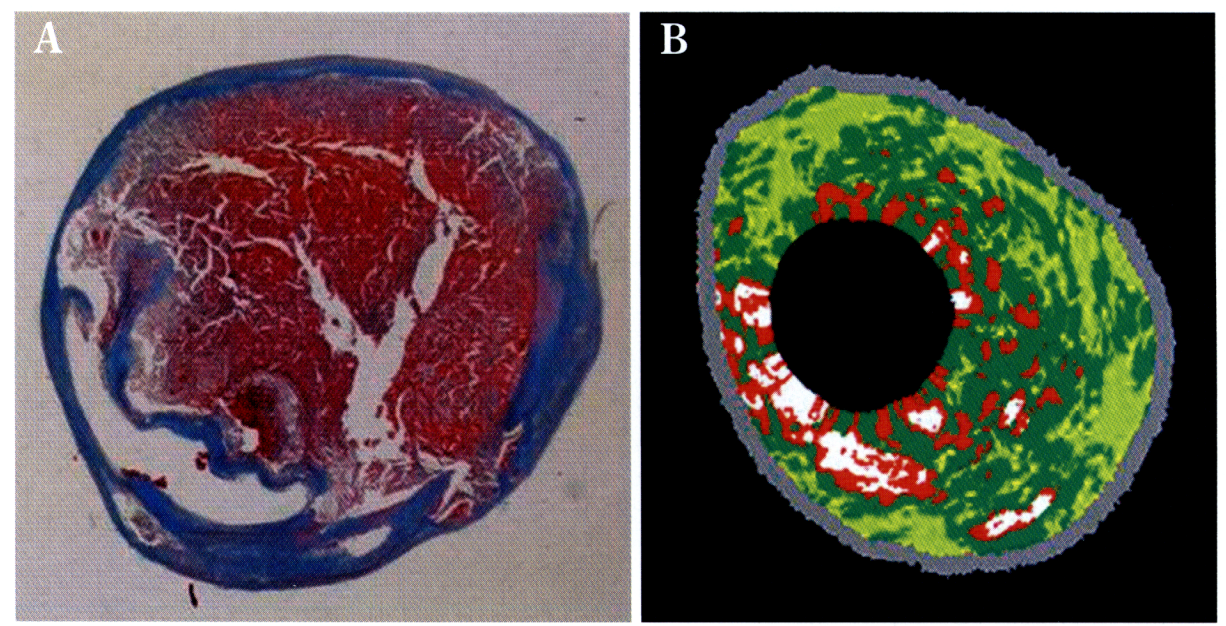

Fig. 1 Histological section showing a large amount of necrotic core rich in IPH (A) (Masson trichrome staining). However, virtual histology analysis of the matched section (B) showed an extremely small area of necrotic core (red) (green : fibrous, light green : fibro-fatty, white: dense calcium).

(median $8.0 \%$ 〔interquartile range $5.0-13.0 \%$ ] vs. $50.0 \%$ [40.0-63.0\%], p<0.0001). 病理組織では necrotic core の増大にプラーク内出血が有意に関与していた $(\mathrm{p}<$ 0.0001）（Table 1）。代表例を Fig. 1 に示す。これらの結 果は頝動脈プラークにおけるプラーク内出血評価の重要 性を示唆しているものと考えられる。また，冠動脈用に 開発された現存の VH アルゴリズムでは出血成分が欠 如しており，これが necrotic core を過小評価する原因と 推定される。VH-IVUS を頝動脈病変に適応するために は, 頝動脈用に出血成分を加味した新しいアルゴリズム が必要と考えられる。

\section{3 脳血管造影}

脳血管造影は狭窄率の測定, 潰瘍の有無, 病変の高位, 頭蓋内側副路の把握に有用であり, 以前は gold standard の検査であった. CEA における無作為比較試験のサブ解 析において，脳血管造影における潰瘍の存在の重要性が 報告されている. Eliasziw ら ${ }^{8)}$ は North American Symptomatic Carotid Endarterectomy Trial (NASCET) において, Rothwell ら ${ }^{34)}$ は European Carotid Surgery Trial（ECST)
において，潰瘍の存在は脳卒中発生率を有意に上昇させ ると報告している。しかしながら，現在は脳血管造影自 体の侵襲性の問題から, 特に CEA の周術期は 3D-CT angiography で代用している施設も多いと思われる。また プラークイメージングの観点から, 脳血管造影から得ら れる所見は血管内腔のみの情報に限定され，プラーク自 体の性状評価には限界があると思われる。

\section{MRI}

MRI は非侵襲性，広い普及率，軟部組織の良好なコン トラスト，被曝しない点などからプラークイメージング に適しており，日常診療で汎用されている modality であ る.

Spagnoli ら ${ }^{38)}$ は，プラーク内出血が虚血イベントに有 意に相関することを報告しており，その他にもプラーク 内出血検出を主眼とした MRI の有用性を論じた報告が 多数存在する25)16)17)23)39)40)44)45)。 Yuan ら ${ }^{45)}$ は, T1 強調 法, T2 強調法, proton density, 3D TOF による multiple contrast technique を用いて，感度 $85 \%$ ，特異度 $92 \%$ と いう高い necrotic core ならびにプラーク内出血の検出 
Table 2 Percentages of histologic sections with high and low signals on MPRAGE in IPH score 1, 2 and 3

\begin{tabular}{cccc}
\hline & High & Low & p value \\
\hline IPH score 1 & $14.3 \%$ & $85.7 \%$ & \\
IPH score 2 & $25.0 \%$ & $75.0 \%$ & $<0.0001$ \\
IPH score 3 & $64.3 \%$ & $35.7 \%$ & \\
\hline
\end{tabular}
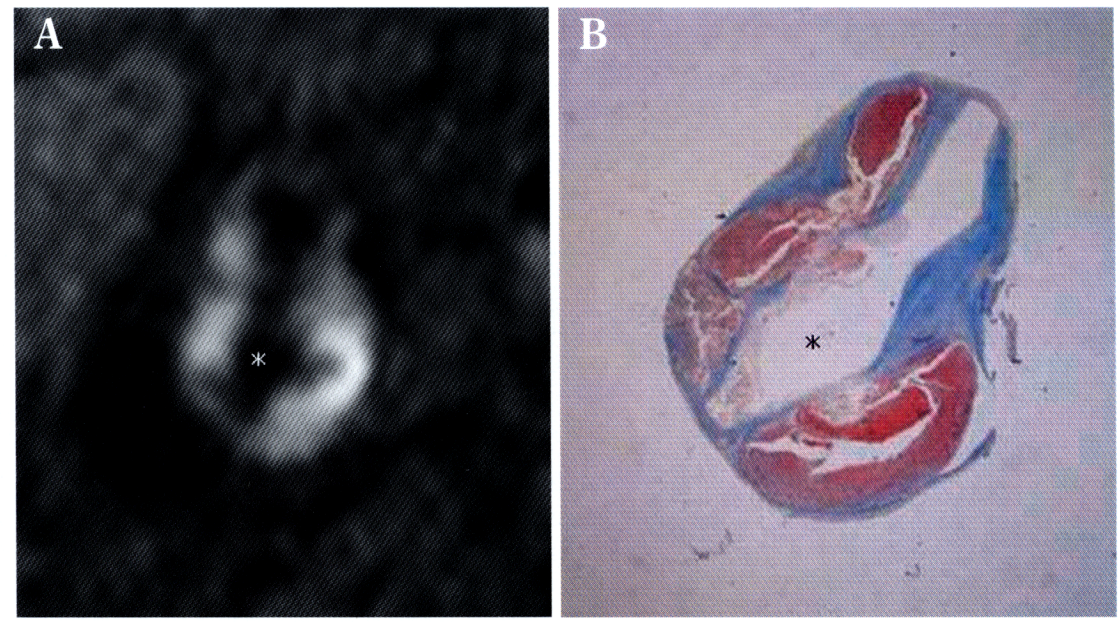

Fig. 2 An example of plaque with high signal intensity

A : An MPRAGE image showing the plaque.

B : A photomicrograph of a histological section stained with Masson trichrome showing a large amount of necrotic core with IPH.

Asterisks indicate the internal carotid artery lumen.
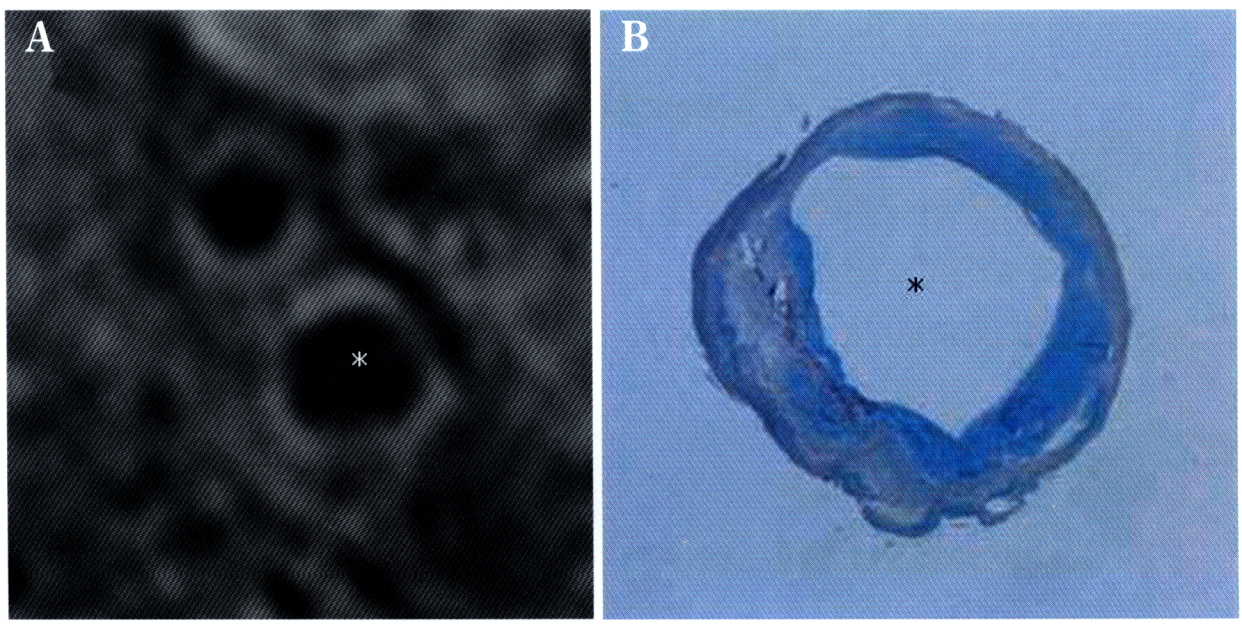

Fig. 3 An example of plaque with lower signal intensity

A : An MPRAGE image showing the plaque.

B : A photomicrograph of an internal carotid artery section stained with Masson trichrome shows that the plaque mainly consists of fibrous tissue.

Asterisks indicate the internal carotid artery lumen. 
A

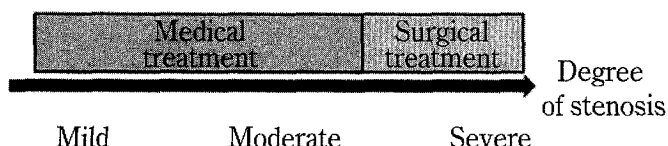

B

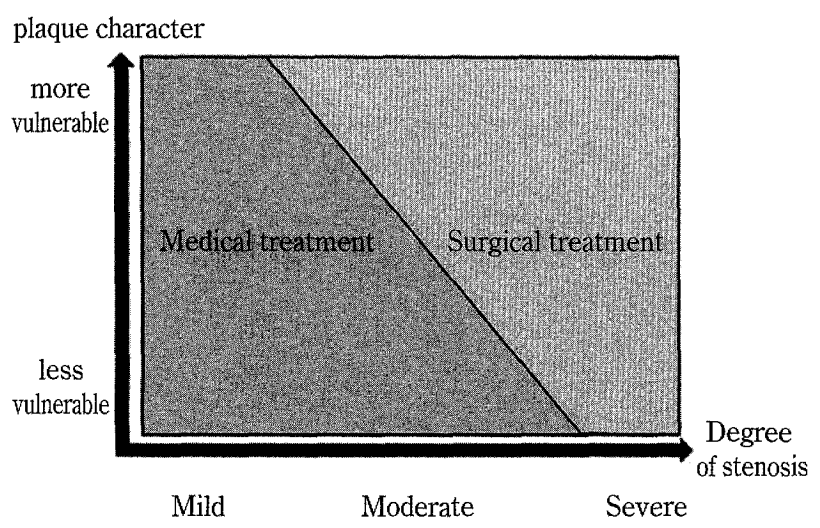

Fig. 4 A schematic illustration showing onedimensional (A) and two-dimensional (B) therapeutic strategies for carotid artery stenosis.

率を報告している. Moody ら ${ }^{23)}$ は，T1 強調法 (direct thrombus imaging）のみを用いる single contrast technique で, 感度, 特異度ともに $84 \%$ でプラーク内出血が 検出可能であったと報告している。われわれはプラーク イメージングに高速三次元 T1 強調法の一種である MPRAGE (magnetization prepared rapid acquisition with gradient echo）法を用いている ${ }^{16)}$ 。これは Moody ら ${ }^{23) か ゙ ~}$

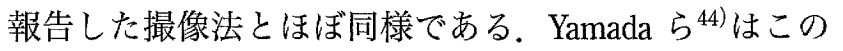
MPRAGE 法を用い，プラーク内最大信号強度が胸鎖乳 突筋の $200 \%$ 以上を高信号と定義し, 過去の虚血イベン トとの相関を検討した。中等度, 高度狭窄で高信号は低 信号に比べ有意に多くの過去の虚血イベントを認めた。 さらに高信号を呈するプラークの相刘危険度は中等度狭 窄で 7.548 倍, 高度狭窄で 1.982 倍であった。これは高 度狭窄ではその狭窄率自体が症候化のリスクになるが， 中等度狭窄は症候化にプラーク性状が関与していること を示しており，プラークイメージングの重要性を考える うえで大変興味深い。われわれ ${ }^{16)}$ は，その背景となる病 理所見を検討するために, CEA 摘出標本を用い, MRI と 病理組織の比較検討試験を行った. CEA 対象群のため高 度狭窄例が検討対象となるが, 高信号は低信号に比心゙有 意に necrotic core が大きく (median 51.2\%〔interquartile range $43.3-66.8 \%]$ vs. $49.0 \%[33.2-57.6 \%], \mathrm{p}=0.029)$, プラーク内出血の程度も有意に強かった $(\mathrm{p}<0.0001)$
（Table 2)，高信号，低信号を示す代表症例を提示する (Fig. 2，3）. MPRAGE 法はプラーク内出血を伴う necrotic core の増大の検出に有用である。

炎症も plaque vulnerability の重要な要素であるが, Kooi $ら^{21)}$ Privedi $ら^{42)}$ は ultrasmall superparamagnetic particles of iron oxide（USPIO）投与により, USPIO が macrophage に取り込まれることで MR での可視化が可 能となり，プラーク内の炎症の把握に有用であると報告 している.

Fibrous cap の厚さや破綻の評価についても報告され ている. Hatsukami ら ${ }^{14)}$ は 3D multiple overlapping thin slab angiography (MOSTA) sequence を用い, fibrous cap を(1)intact, thick, (2)intact thin, (3)ruptured に分類L, MRI と病理組織を比較している. 結果, MRI は高い精度で fibrous cap の形態を判定できるとしている.

このように MRI に関しては multifactorial に検証が行 われているが, 最大の課題として各施設で撮像条件が千 差万別であることが挙げられる，撮像法は sequence の 構造から大きく spin echo 法と gradient echo 法に分類さ れる.プラーク内出血検出の観点からは gradient echo 法 は spin echo 法より優れているとの報告がある4)30)が, 多 くの施設が spin echo 法を採用している. Multiple contrast technique と single contrast technique のどちらで性 状評価を行うかも課題である. Multiple contrast technique では necrotic core, loose matrix や fibrous tissue な ぞのプラークの構成成分を評価できるが ${ }^{36)}$, 複数の画像 を組み合わせて評価を行う点で, その客観性が問題とな る. Single contrast technique は T1 強調画像を用い, 主 に血栓特異的な撮像法であるが23)，言い換えればプラー ク内出血以外の評価にそしい. 他, $1.5 \mathrm{~T} と 3.0 \mathrm{~T}$ の MRI を比較した報告 ${ }^{43}$ や Siemens 社, Philips 社と General Electric（GE）社を比較した報告 ${ }^{37)}$ が存在する。このよ うに, 頚動脈プラークイメージングとしての MRI は急速 に発展してきたが，その反面，臨床現場では評価項目や 撮像条件に掞いて混沌としているのが現状である。一方 で, 近年 CAS の遠位塞栓予防の device の選択に MRI で のプラーク性状の分析を反映させるなど, 頝動脈狭窄症 に対する management において MRI の需要はますます 高まっている. MRI を有益にかつ適切に内科治療, 外科 治療に介入させるためには撮像条件の標準化が重要と思 われる。

\section{PET}

Tawakol $~^{41)}{ }^{18} \mathrm{~F}$-Fluorodeoxyglucose (FDG)-PET を用いて検討を行い，プラークの炎症と FDG uptake の 
有意な相関を報告している。しかしながら PET による プラークイメージングは解像度に限界があり，また PET 検査自体の保険適応の問題から，本邦ではまだ普及 していないのが現状である.

\section{6] CT}

de Weert $ら^{6)} は$ multidetector CT を用いて, 病理組織 との比較を行っている. total plaque area, calcification, fibrous tissue については良好に検出されたが， lipid core については石灰化が少ない症例にのみ検出が可能であつ たと報告している。

\section{おわりに}

現在の䅡動脈狭窄症に対する外科治療適応は，狭窄率 を軸とした一次元的な適応である（Fig. 4A）. 頝動脈プ ラークイメージングにより症候学的な危険性（無症候性 病変であれば将来の症候化の危険性, 症候性病変であれ ば再発の危険性）が予知できれば，本来内科治療適応で ある中等度, 軽度狭窄例が外科治療へシフトする可能性 があり，一方で無症候性高度狭窄例において症候学的に 危険性の少ない例はス夕チンなどの薬物治療の進歩に伴 い，より積極的に内科治療を行うことができる，つまり 狭窄率の軸にプラーク性状の軸を加えることにより二次 元的な治療適応を議論することが可能となる（Fig. 4B）. さらにプラークイメージングによる外科手技中に塞栓合 雁症をきたしやすい危険なプラークの検出は，外科治療 の手技選択（CEAもしくは CAS，CASにおける distal protection の選択) の一助となる. 今後, プラークイメー ジングを駆使して頝動脈プラークの本質に迫ることによ り, 頝動脈狭窄症への対応がより論理的に展開されるこ とが期待される。

\section{文 献}

1) AbuRahma AF, Wulu JT, Crotty B: Carotid plaque ultrasound heterogeneity and severity of stenosis. Stroke 33 : 1772-1775, 2002.

2) Altaf N, MacSweeney ST, Gladman J, Auer DP: Carotid intraplaque hemorrhage predicts recurrent symptoms in patients with high-grade carotid stenosis. Stroke 38: 1633-1635, 2007.

3) Barnett HJM, Taylor DW, Eliasziw M, Fox AJ, Ferguson GG, Haynes RB, Rankin RN, Clagett GP, Hachinski VC, Sackett DL, Thorpe KE, Meldrum HE: The North American Symptomatic Carotid Endarterectomy Trial Collaboraotors: Benefit of carotid endarterectomy in patients with symptomatic moderate or severe stenosis. $N$ Engl J Med 339: 1415-1425, 1998.

4) Cappendijk VC, Cleutjens KBJM, Heeneman S, Schurink
GWH, Welten RJTJ, Kessels AGH, van Suylen RJ, Daemen MJAP, van Engelshoven JMA, Kooi ME: In vivo detection of hemorrhage in human atherosclerotic plaques with magnetic resonance imaging. $J$ Magn Reson Imaging 20 : 105-110, 2004.

5) Chu B, Kampschulte A, Ferguson MS, Kerwin WS, Yarnykh VL, O'Brien KD, Polissar NL, Hatsukami TS, Yuan $\mathrm{C}$ : Hemorrhage in the atherosclerotic carotid plaque: A high-resolution MRI study. Stroke 35: 10791084, 2004.

6) de Weert TT, Ouhlous M, Meijering E, Zondrvan PE, Hendriks JM, van Sambeek MRHM, Dippel DWJ, van der Lugt A: In vivo characterization and quantification of atherosclerotic carotid plaque components with multidetector computed tomography and histopathological correlation. Arterioscler Thromb Vasc Biol 26: 2366-2372, 2006.

7) Diethrich EB, Margolis MP, Reid DB, Burke A, Ramaiah V, Rodriguez-Lopez JA, Wheatley G, Olsen D, Virmani R: Virtual histology intravascular ultrasound assessment of carotid artery disease: The Carotid Artery Plaque Virtual Histology Evaluation (CAPITAL) Study.J Endovasc Ther 14:676-686, 2007.

8) Eliasziw M, Streifler JY, Fox AJ, Hachinski VC, Ferguson GG, Barnett HJM : Significance of plaque ulceration in symptomatic patients with high-grade carotid stenosis. Stroke 25: 304-308, 1994.

9) European Carotid Surgery Trialists' Collaborative Group: MRC European Carotid Surgery Trial: Interim results for symptomatic patients with severe $(70-99 \%)$, or with mild (0-29\%), carotid stenosis. Lancet 337:1235-1243, 1991.

10) Executive Committee for Asymptomatic Carotid Atherosclerosis Study: Endarterectomy for asymptomatic carotid artery stenosis. JAMA 273: 1421-1428, 1995.

11) Falk E, Shah PK, Fuster V: Coronary plaque disruption. Circulation 92:657-671, 1995.

12) Golledge J, Greenhalgh RM, Davies AH: The symptomatic carotid plaque. Stroke 31: 774-781, 2000.

13) Halliday A, Mansfield A, Marro J, Peto C, Peto R, Potter J, Thomas D: MRC Asymptomatic Carotid Surgery Trial (ACST) Collaborative Group: Prevention of disabling and fatal strokes by successful carotid endarterectomy in patients without recent neurological symptoms : Randomised controlled trial. Lancet $\quad 363: 1491-1502,2004$.

14) Hatsukami TS, Ross R, Polissar NL, Yuan C: Visualization of fibrous cap thickness and rupture in human atherosclerotic carotid plaque in vivo with high-resolution magnetic resonance imaging. Circulation 102:959-964, 2000.

15) Hishikawa $T$, lihara $K$, Ishibashi-Ueda $H$, Nagatsuka $K$, Yamada N, Miyamoto S: Virtual histology-intravascular ultrasound in assessment of carotid plaques: Ex vivo study. Neurosurgery $\mathbf{6 5}: 146-152,2009$.

16) Hishikawa $T$, Iihara $K$, Yamada $N$, Ishibashi-Ueda $H$, Miyamoto $\mathrm{S}$ : Assessment of necrotic core with intraplaque hemorrhage in atherosclerotic carotid artery plaque by MR imaging with 3D gradient-echo sequence in patients with high-grade stenosis. $J$ Neurosurg [epub ahead of print, April 9, 2010. DOI : 10.3171/2010.3. JNS091057].

17) Kampschulte A, Ferguson MS, Kerwin WS, Polissar NL, Chu B, Saam T, Hatsukami TS, Yuan C: Differentiation of intraplaque hemorrhage versus juxtaluminal hemorrhage/ 
thrombus in advanced human carotid atherosclerotic lesions by in vivo magnetic resonance imaging. Circulation 110:3239-3244, 2004.

18) Kawaguchi $R$, Oshima $S$, Jingu $M$, Tsurugaya $H$, Toyama T, Hoshizaki $\mathrm{H}$, Taniguchi $\mathrm{K}$ : Usefulness of virtual histology intravascular ultrasound to predict distal embolization for ST-segment elevation myocardial infarction. J Am Coll Cardiol 50: 1641-1646, 2007.

19) Kawamoto T, Okura H, Koyama $Y$, Toda I, Taguchi $H$, Tamita K, Yamamuro A, Yoshimura Y, Neishi Y, Toyota E, Yoshida $\mathrm{K}$ : The relationship between coronary plaque characteristics and small embolic particles during coronary stent implantation. I Am Coll Cardiol 50: 16351640, 2007.

20) Kolodgie FD, Gold HK, Burke AP, Fowler DR, Kruth HS, Weber DK, Farb A, Guerrero LJ, Hayase M, Kutys R, Narula J, Finn AV, Virmani R: Intraplaque hemorrhage and progression of coronary atheroma. $N \mathrm{Engl} \mathrm{J} \mathrm{Med}$ 349: 2316-2325, 2003.

21) Kooi ME, Cappendijk VC, Cleutjens KBJM, Kessels AGH, Kitslaar PJEHM, Borgers M, Frederik PM, Daeman MJAP, van Engelshoven JMA : Accumulation of ultrasmall superparamagnetic particles of iron oxide in human atherosclerotic plaques can be detected by in vivo magnetic resonance imaging. Circulation 107: 2453-2458, 2003.

22) Matsumoto S, Nakahara I, Higashi T, Iwamuro $Y$, Watanabe Y, Takezawa M, Murata D, Yokota T, Kira J, Yamada T: Fibro-fatty volume of culprit lesions in virtual histology intravascular ultrasound is associated with the amount of debris during carotid artery stenting. Cerebrovasc Dis 29: 468-475, 2010.

23) Moody AR, Murphy RE, Morgan PS, Martel AL, Delay GS, Allder S, MacSweeney ST, Tennant WG, Gladman J, Lowe J, Hunt BJ : Characterization of complicated carotid plaque with magnetic resonance direct thrombus imaging in patients with cerebral ischemia. Circulation 107:30473052, 2003.

24）長束一行：頝動脈の超音波検査. J Jpn Coll Angiol 44： 715-720, 2004.

25) Naghavi M, Libby P, Falk E, Casscells SW, Litovsky S, Rumberger J, Badimon JJ, Stefanadis C, Moreno P, Pasterkamp G, Fayad Z, Stone PH, Waxman S, Raggi P, Madjid M, Zarrabi A, Burke A, Yuan C, Fitzgerald PJ, Siscovick DS, de Korte CL, Aikawa M, Airaksinen KEJ, Assmann G, Becker CR, Chesebro JH, Farb A, Galis ZS, Jackson C, Jang IK, Koenig W, Lodder RA, March K, Demirovic J, Navab M, Priori SG, Rekhter MD, Bahr R, Grundy SM, Mehran R, Colombo A, Boerwinkle E, Ballantyne C, Insull, Jr. W, Schwartz RS, Vogel R, Serruys PW, Hansson GK, Faxon DP, Kaul S, Drexler H, Greenland P, Muller JE, Virmani R, Ridker PM, Zipes DP, Shah PK, Willerson JT: From vulnerable plaque to vulnerable patient. A call for new definitions and risk assessment strategies: Part 1. Circulation 108: 1664-1672, 2003.

26) Nair A, Kuban BD, Tuzcu M, Schoenhagen P, Nissen SF, Vince $\mathrm{G}$ : Coronary plaque classification with intravascular ultrasound radiofrequency data analysis. Circulation 106 : 2200-2206, 2002.

27) Nasu K, Tsuchikane E, Katoh O, Vince G, Virmani R, Surmely JF, Murata A, Takeda Y, Ito T, Ehara M, Matsubara T, Terashima M, Suzuki T: Accuracy of in vivo coronary plaque morphology assessment. A validation study or in vivo virtual histology compared with in vitro histopathology. J Am Coll Cardiol 47:2405-2412, 2006.

28) Nissen SE, Yock P: Intravascular ultrasound. Novel pathophysiological insights and current clinical applications. Circulation 103: 604-616, 2001.

29) North American Symptomatic Carotid Endarterectomy Trial Collaborators: Beneficial effect of carotid endarterec tomy in symptomatic patients with high-grade carotid stenosis. N Engl J Med 325: 445-453, 1991.

30) Ota H, Yarnykh VL, Ferguson MS, Underhill HR, DeMarco JK, Zhu DC, Oikawa M, Dong L, Zhao X, Collar A, Hatsukami TS, Yuan C: Carotid intraplaque hemorrhage imaging at 3.0-T MR imaging: Comparison of the diagnostic performance of three $\mathrm{T} 1$-weighted sequences. Radiology 254: 551-563, 2010.

31) Polak JF, Shemanski L, O'Leary DH, Lefkowitz D, Price TR, Savage PJ, Brant WE, Reid C: Hypoechoic plaques at US of the carotid artery: An independent risk factor for incident stroke in adults aged 65 years or older. Radiology 208: 649-654, 1998.

32) Redgrave JNE, Lovett JK, Gallagher PJ, Rothwell PM: Histological assessment of 526 symptomatic carotid plaques in relation to the nature and timing of ischemic symptoms. The Oxford Plaque Study. Circulation 113: 2320-2328, 2006.

33) Reid DB, Diethrich EB, Marx P, Wrasper R: Intravascular ultrasound assessment in carotid interventions. $J$ Endovasc Surg $3: 203-210,1996$.

34) Rothwell PM, Gibson R, Warlow CP: Interrelation between plaque surface morphology and degree of stenosis on carotid angiograms and the risk of ischemic stroke in patients with symptomatic carotid stenosis. Stroke 31 : 615-621, 2000.

35) Rothwell PM, Gutnikov SA, Warlow CP: The European Carotid Surgery Trialists' Collaboration: Reanalysis of the final results of the European Carotid Surgery Trial. Stroke 34: 514-523, 2003.

36) Saam T, Ferguson MS, Yarnykh VL, Takaya N, Xu D, Polissar NL, Hatsukami TS, Yuan C: Quantitative evaluation of carotid plaque composition by in vivo MRI. Arterioscler Thromb Vasc Biol 25: 234-239, 2005.

37) Saam T, Hatsukami TS, Yarnykh VL, Hayes CE, Underhill H, Chu B, Takaya N, Cai J, Kerwin WS, Xu D, Polissar NL, Neradilek B, Hamar WK, Maki J, Shaw DW, Buck RJ, Wyman B, Yuan C: Reader and platform reproducibility for quantitative assessment of carotid atherosclerotic plaque using 1.5T Siemens, Philips, and General Electric scanners. J Magn Reson Imaging 26:344-352, 2007.

38) Spagnoli LG, Mauriello A, Sangiorgi G, Fratoni S, Bonanno E, Schwartz RS, Pirpgras DG, Pistolese R, Ippoliti A, Holmes DR Jr: Extracranial thrombotically active carotid plaque as a risk factor for ischemic stroke. JAMA 292: 1845-1852, 2004.

39) Takaya N, Yuan C, Chu B, Saam T, Polissar NL, Jarvik GP, Isaac C, McDonough J, Natiello C, Small R, Ferguson MS, Hatsukami TS: Presence of intraplaque hemorrhage stimulates progression of carotid atherosclerosis plaques. A high-resolution magnetic resonance imaging study. Circulation 111:2768-2775, 2005.

40) Takaya N, Yuan C, Chu B, Saam T, Underhill H, Cai J, Tran N, Polissar NL, Isaac C, Ferguson, MS, Garden GA, Cramer SC, Maravilla KR, Hashimoto B, Hatsukami T: 
Association between carotid plaque characteristics and subsequent ischemic cerebrovascular events. A prospective assessment with MRI-Initial results. Stroke 37: 818-823, 2006.

41) Tawakol A, Migrino RQ, Bashian GG, Bedri S, Vermylen D, Cury RC, Yates D, LaMuraglia GM, Furie K, Houser S, Gewirtz H, Muller JE, Brady TJ, Fischman AJ: In vivo ${ }^{18} \mathrm{~F}$-fluorodeoxyglucose positron emission tomography imaging provides a noninvasive measure of carotid plaque inflammation in patients. $J$ Am Coll Cardiol 48:18181824, 2006.

42) Trivedi RA, Mallawarachi C, U-King-Im JM, Graves MJ, Horsley J, Goddard MJ, Brown A, Wang L, Kirkpatrick PJ, Brown J, Gillard JH: Identifying inflamed carotid plaques using in vivo USPIO-enhanced MR imaging to label plaque macrophage. Arterioscler Thromb Vasc Biol 26: 1601-1606, 2006.
43) Underhill HR, Yarnykh VL, Hatsukami TS, Wang J, Balu $\mathrm{N}$, Hayes CE, Oikawa M, Yu W, Xu D, Chu B, Wyman B, Polissar N, Yuan C: Carotid plaque morphology and composition: Initial comparison between $1.5^{-}$and 3.0-T magnetic field strengths. Radiology 248: 550-560, 2008.

44) Yamada N, Higashi M, Otsubo R, Sakuma, T, Oyama N, Tanaka R, lihara K, Naritomi $H$, Minematsu $K$, Naito $H$ : Association between signal hyperintensity on $\mathrm{T} 1-$ weighted MR imaging of carotid plaques and ipsilateral ischemic events. Am J Neuroraidol 28: 287-292, 2007.

45) Yuan C, Mitsumori LM, Ferguson MS, Polissar NL, Echelard D, Ortiz G, Small R, Davies JW, Kerwin WS, Hatsukami TS: In vivo accuracy of multispectral magnetic resonance imaging for identifying lipid-rich necrotic cores and intraplaque hemorrhage in advanced human carotid plaques. Circulation 104:2051-2056, 2001.

\section{要 旨}

頝動脈プラークイメージングの現状と展望

\begin{tabular}{|c|c|c|}
\hline 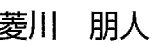 & 飯原 & 弘二 \\
\hline 綀 一行 & 宮本 & 与 \\
\hline
\end{tabular}

現在の頚動脈狭窄症の治療方針は，主に狭窄率によって決定される. 頝動脈プラークイメージング は，プラークの本質を客観的にかつ非侵襲的に追究する手法であり，近年その発展は目覚ましい，狭 窄率に加えプラークイメージングが頚動脈狭窄症の治療選択に介入することにより，プラーク性状を 勘案したより論理的な治療展開が期待される. 本論文では超音波，血管内超音波，脳血管造影，magnetic resonance imaging (MRI), positron emission tomography (PET), computed tomography （CT）について概説し，頚動脈プラークイメージングの現状と展望について述べる。 